\title{
CONSTITUTIONAL REFORM OF THE CANADIAN JUDICIARY
}

\author{
PETER H. RUSSELL*
}

\begin{abstract}
A consideration of both the judicial sections of the B.N.A. Act and the public expectations concerning the judiciary suggest three basic norms which are relevant to the exercise of judicial power in the Canadian Constitutional system-the independence of the judiciary, bilingualism and biculturalism, and federalism. The author analyzes the Canadian judiciary from the point of view of each of these precepts and makes suggestions for constitutional reform of the Canadian Judiciary.
\end{abstract}

The question of reforming the judicial provisions of the Canadian Constitution must first be put in the general context of constitutional reform in Canada. I am certainly one of those who wholeheartedly favours a broad-based reconstruction and repatriation of the Canadian Constitution. And it can be said that as of February, 1968, the federal government and the provinces are committed to begin working towards a revision of the Constitution. The immediate cause of this current interest in constitutional reform is, of course, the political confrontation between Quebec and the rest of Canada. In this context constitutional revision is apt to be approached by government negotiators primarily as a matter of political tactics. Up to a point that is both unavoidable and appropriate, for the classic purpose of constitutional settlements has been to crystallize the resolution of basic conflict in the body politic. But a constitution should also serve a more timeless purpose: for the on-going public life of the polity it should establish the fundamental norms governing the ways in which authoritative power may be acquired, distributed and exercised. In a democratic age, to be effective these basic constitutional principles must be widely accepted and understood throughout the community. It is in this latter respect that the existing Constitution, the B.N.A. Act, is most wanting, and it is this inadequacy which provides the deeper reason for constitutional reform at this time.

The opening phrase of the American Constitution, "We the people of the United States, in Order to form a more perfect Union, . . . ," provides the main clue to the basic difference between the status and role of the written constitution in our two countries. Granted there is an element of political mythology in those initial words of the U.S. Constitution, but still it is a mythology with very real roots in the American political culture. For certainly the United States' Constitution is much more a product and a possession of the popular political conscience of that country than is the B.N.A. Act, with its colonial origins and Imperial trappings, of ours. In practical terms this means that in Canada there is an insufficient common understanding-at the political level-of the content and the purpose of the important provisions of the Constitution, with the result that in constitutional politics almost anything goes because few people know. It is in overcoming this situation that repatriation and revision of the B.N.A. Act should find its deepest meanings-for what is involved is replacing the Imperial Parliament

- Professor of Political Economy. the University of Toronto. This paper was prepared for the Annual Meeting of the Association of Canadian Law Teachers held in Calgary in June, 1868. 
with the consciousness of politically active Canadians as the final custodian, the basic anchor of our fundamental law. At stake in this enterprise is nothing less than the opportunity of becoming a nation which is at once both democratic and constitutional. This is surely not an easy undertaking, and probably a risky one, but one which I personally would be ashamed to be too timid to undertake.

Viewed, then, from this broad perspective of constitutional reform, what is to be done with the judiciary? At the present time the only aspect of the judicial system which is a live political issue is the status and structure of the Supreme Court of Canada. The new Prime Minister, Mr. Trudeau, has indicated that reform of the Supreme Court is one of his top priorities. His view that ". . . conflicts in jurisdiction between federal and provincial levels could be judged by an independent body deriving its authority directly from the Constitution" ${ }^{1}$ has been, at least since the Tremblay Commission's Report of 1965, a basis of the Quebec government's discontent with the Court." There has also been in Quebec, especially among academic lawyers, a resurgence of the classical Quebec protest against the Supreme Court's appellate jurisdiction over Quebec's Civil Law. ${ }^{3}$ While the Supreme Court issue will be dealt with here, it is a mistake to approach this issue in isolation from the other dimensions of the judiciary which are affected by the Constitution. The simple ad hoc approach overlooks the way in which changes in one branch of the judicial system may affect other parts of the judicial structure, and, what is more important, does not give adequate consideration to the overriding constitutional principles which ought to govern judicial power. The approach taken here will place these principles at the forefront of the analysis of the existing constitutional provisions and their possible reform.

\section{The Basic Norms}

A consideration of both the judicial sections of the B.N.A. Act and public expectations concerning the judiciary suggest three basic values or norms which are relevant to the exercise of judicial power in the Canadian constitutional system-the independence of the judiciary, bilingualism and biculturalism, and federalism. It should be noted that only the first of these precepts, judicial independence, specifically pertains to the administration of justice. The latter two principles concern the fundamental rights and system of grovernment in Canada's constitutional system. It is important for lawyers to realize that, in considering how far and in what ways these latter principles should be applied to Canada's judicial system, the primary concern must be the extent to which the nation's underlying constituent norms should be manifest in its judicial organization. For this reason the constitutional clauses concerning the judiciary cannot be assessed solely in terms of their effect on the administration of justice. Objections to constitutional proposals based solely on the view that they may make the administration of justice more complex or less efficient must be balanced against the larger con-

1 Trudeau, Federalism and the French-Canadians 45 (1968).

2 Province of Quebec, 3 Report of the Royal Commission of Inquiry on Constitutional

s Problems, ch. $X$. Ar instance Azard, La Cour Suprême du Canada et l'application du droit civil de la Province de Quebec (1965), 43 Can. Bar Rev. 553, and Morin, Vers un Nouvel Equilibre Constitutionel au Canada, in P.-A. Crépeau \& C. B. MacPherson (eds.), The Future of Canadian Federalism 141 (1965). 
cern of developing a Constitution which gives the fullest possible expression to the most basic political and social ideals of the Canadian people.

For purposes of analysis each of these principles shall be examined in turn. It must be admitted that there is a certain artificiality in this procedure, for these principles are often interwoven in the actual provisions of the Constitution. Still it is worthwhile to see the different values which are at stake in a single section of the Constitution, so that in the end when certain concrete revisions of the B.N.A. Act are proposed we can clearly perceive the priorities-the ordering of valuesupon which they are based.

\section{THE INDEPENDENCE OF THE JUDICIARY}

As a basic principle of government, in Great Britain since the 18th century and in Canada since the mid-19th century, judicial independence has meant at the very least that the judges of the principal courts should be as free as possible from interference by the other branches of government. ${ }^{4}$ The classic device for achieving this ideal, following the formula of the Act of Settlement of 1701, has been to grant the judges of superior courts security of tenure and remuneration. The B.N.A. Act makes some provision for this particular means of ensuring judicial independence. Section 99 uses the classic language of the Act of Settlement in declaring that the "Judges of the Superior Courts shall hold office during good behaviour, but shall be removable by the Governor-General on Address of the Senate and the House of Commons." Since 1960 this provision has been qualified by a compulsory retirement age for Superior Court judges of 75 years. There is no clear protection of the judges' salaries in the B.N.A. Act, although it has been argued that section 100 which authorizes Parliament to fix and provide for the salaries of Superior, District and County Court judges, when read in conjunction with the other judicial clauses of the Act, has the force of giving Canadian Superior-Court judges the same protection from punitive or discriminatory reductions in salary as that enjoyed by English Superior Court judges under English statutory law as interpreted by such commentators as Blackstone and Holdsworth. ${ }^{5}$

Now if this were all there was to the question of judicial independence, the only point to be made about the existing constitutional provisions would be to suggest that they be extended to cover federal superior courts, or at least the Supreme Court of Canada and to give clearer protection to salaries. Here again it should be noted that at least one constitutional authority, Professor Lederman, has contended that such an extension is unnecessary, for in his view ". . . the term 'superior court' in sections 99 and 100 includes any federal superior court constituted under section 101," so that ". . . the judges of federal superior courts are in the same position respecting salary, tenure, retirement and removal as judges of the provincial superior courts. ..." However, the legal advisors of the fecieral government do not seem to have shared Professor Lederman's understanding of these sections, for as early as

4 For a perceptive account of the development of this principle in Great Britain and Canada see $W$. R. Lederman, The Independence of the Judiciary (1956), 34 Can. Bar Canada see W.
Rev. 769 , 1139 .

5 Id., at 1163-4. But as Professor Lederman acknowledges, this did not prevent Parliament from levying a special ten per cent levy on judicial salaries in 1932.

Id., at 1176 . 
1927 the federal Parliament enacted a compulsory retirement age for judges of the Supreme Court of Canada without seeing any necessity for a Constitutional amendment. ${ }^{7}$ It is true that by statute both Supreme Court and Exchequer Court judges enjoy the same tenure as that conferred on Superior Court judges by section 99 of the B.N.A. Act, but this of course falls short of a Constitutional guarantee. ${ }^{8}$ There are provisions in the federal Judges Act (covering all judges appointed by the federal executive), which empower the federal executive to discontinue a judge's salary, if on the basis of a judicial inquiry he is found "to have become incapacitated or disabled from the due execution of his office by reason of age or infirmity." This section, to the writer's knowledge, has never been actually used as an indirect method of removing superior court judges, and might even be held unconstitutional if challenged in the courts. ${ }^{10}$ Still it might be thought wise to fill any important gaps in the constitutional guarantees of judicial independence. For this purpose it would be necessary to extend the scope of section 99 to cover federal judges appointed to courts established under section 101 (and perhaps even to County and District Court judges appointed under section 96).11 Further, section 100 could be expanded to provide that all judges appointed by the federal executive should not have their remuneration diminished during their continuance in office. These amendments would afford federally appointed judges in Canada the same constitutional protection as is given such judges by the American and Australian Constitutions. ${ }^{12}$

These would not seem to be very exceptional proposals. While there may be little demand for such a reform at present, it might seem to be a logical way of completing the recognition of the principle of judicial independence in the Canadian Constitution. However, the only part of such a reform which should be considered is to provide a constitutional guarantee for the tenure and salary of judges of the Supreme Court of Canada. There are strong reasons for opposing the expansion of constitutional guarantees to the tenure and salary of other provincial or federal judges. The same reasons should cause us to question the wisdom of retaining the existing constitutional safeguards of provincial judges' security of tenure and remuneration.

There are two kinds of considerations which arise here. One has to do with the proposal to abolish the control which section 96 gives the federal executive over appointments to the Superior, District and County Courts in the provinces and which section 100 gives to the federal parliament over the remuneration of judges appointed to these courts. The merits of giving the provinces the power to appoint and the responsibility of paying their own judges will be argued more fully below when the

7 (Imp.), Geo. V., c. 38, s. 2.

8 Supreme Court Act, R.S.C. 1952, c. 259, s. 9(1), and Exchequer Court Act, R.S.C. 1952, c. $98, \mathrm{~s}$. 6.

o R.S.C. 1952, c. 159 , ss. 31,33 .

10 In 1960 Lester Pearson, John Dlefenbaker and E. D. Fulton, who was then Minister of Justice, all said that they knew of no occasion when this provision had actually been used: (1960) H.C. Deb. 4891. However, there is evidence that Ministers of Justice have threatened to use the section as a way of forcing judges to retire. See Dawson \& Ward, The Government of Canada 439 (4th ed. 1963).

11 The Conservative Government in 1960 planned to extend the guaranteed tenure to these judges, but had to abandon this part of the Judges Amendment when it was vetoed by the Liberal majority in the Senate. (1960) H.C. Deb. 7205 .

12 Article III, section 2 of the U.S. Constitution guarantees the tenure and salaries of all federal judges. Sub-sections (II) and (III) of Section 72 in the Australlan Constitution does the same for federal judges in that country. 
question of the appropriate role of federalism in Canada's judicial arrangements is discussed. But here it must be anticipated that one immediate consequence of eliminating sections 96 and 100 from the B.N.A. Act without changing section 99 would be that judges appointed by the provinces could be removed only by federal authorities. This situation could easily be rectified by a new constitutional provision securing office during good behavior for the judges of provincial superior courts subject to removal by the Lieutenant-Governor of the province on address of the provincial legislature. But here there must be taken into account a second and far more serious consideration that throws doubt upon the desirability of any generalized constitutional guarantee of judicial tenure-the particular mode of judicial review which such a guarantee makes possible.

Canadians have already had some experience with the way in which courts exercising their power of judicial review can employ a constitutional guarantee of judicial independence to veto new arrangements for administering laws. Here reference is made to the judicial decisions in which the courts have struck down provincial schemes assigning functions to provincially appointed officials or judges on the grounds that such functions were inherently the responsibility of those provincial courts over which section 96 of the B.N.A. Act gave the federal executive and exclusive power of appointment. ${ }^{13}$ On their face these decisions may seem to turn solely on the federal appointing power in section 96 , but in fact they have had a double rationale. One of their purposes has certainly been to keep provincial appointees from usurping the places in the provincial administration of justice reserved by section 96 for federal appointees. This is at once the less consequential and more indefensible motif of these cases. For unless one is prepared to argue that the Canadian provinces, unlike the constituent units of all other federal states, cannot be trusted to appoint the judges of their own courts, this particular function of these decisions can scarcely be regarded as the fulfillment of a great and enduring constitutional principle. But assuming for the moment that we are prepared to grant the provinces the power of appointing their own judges, there remains a deeper logic to these decisions. For in its headier, more ideological moments, the enforcement of section 96 has been linked with sections 99 and 100 , and regarded as having the wider purpose of preserving for courts of law a primary role in applying laws. In this context sections 99 and 100 , with their guarantees of tenure and "fixed" salaries, have been regarded as defining two of the necessary marks of those courts of law whose jurisdiction the enforcement of section 96 is designed to preserve. Thus, it is found that in the first Privy Council decision, the Martineau case of 1932, which encouraged Canadian judges to squeeze a division of powers concept out of the judicial provisions of the B.N.A. Act, Lord Blanesburgh associated section 96 with sections 99 and 100 as "the means

13 By Canadian standards, the literature on this particular aspect of judiclal review is almost voluminous. The leading articles are Willis, Section 96 of the British North America Act (1940), 18 Can. Bar Rev. 517 and Administrative Law and the British North America Act (1939), 53 Harv. L. Rev. 251; Morris C. Shumiatcher, Section 96 of the British North America Act Re-examined (1949), 27 Can. Bar Rev. 131; Laskin, Municipal Tax Assessment and Section 96 of the British North America Act; The Olympia Bowling Alleys Case (1955), 33 Can. Bar Rev. 993 and Provincial Administrative Tribunals and Judicial Power-The Exaggeration of Section Provincial Administrative Tribunals and Judicial Power-The Exaggeration of Section
96 of the British North America Act-Authority of Provincial Labour Relations Boards (1963), 41 Can. Bar Rev. 446; and Part II of Professor Lederman's article, op. cit. supra, n. 4 . 
adopted by the framers of the statute to secure the impartiality and the independence of the Provincial judiciary."14 A few years later, in the decision which capped the development of this doctrine, Lord Atkin found as the constitutional basis for his view that it would be invalid for a province to vest "the functions of a court" in a provincial administrative board in the combined force of sections 96,99 and 100 , which he designated as the "three pillars in the temple of justice."1s

Now, no matter how willing one may be to dismantle sections 96,99 and 100 in the name of federalism, there is likely to be a considerable body of opinion, particularly among lawyers, for retaining the separation of powers doctrine which judicial construction has found embedded in those sections. And I would agree with Professor Lederman that this could be done by simply recasting these sections so that they apply to judges appointed and removed by provincial authorities. So, quite independently of any considerations which may stem from the concern for federalism, the question of whether we wish to retain or restore in the Canadian Constitution a certain guaranteed minimum of curial control over the application of laws must be confronted.

This is not an easy question to answer. There is certainly an inherent logic in invoking the constitutional clauses protecting the tenure and salaries of judges as a justification for cutting down legislation which assigns to other officials aspects of legal administration traditionally carried out by judges. These constitutional provisions designed to guarantee the impartiality and independence of judges would be of little avail if legislatures were free to transfer more and more of the law-applying functions to non-courts and non-judges; such provisions are only meaningful so long as judges carry out meaningful tasks. Canadian jurists are not unreasonable in inferring that a limited separation of powers in the form of a guaranteed jurisdiction for tribunals manned by constitutionally protected judges is a necessary corollary of the constitutional guarantee of judicial independence. Nor are they alone in following this course of reasoning. Australian judges have similarly found in the constitutional clause protecting the tenure and salary of federal judges a justification for cutting down administrative schemes established by the federal legislature. ${ }^{16}$

The quarrel here is not with the logic of linking a separation of power concept to a constitutional guarantee of judicial independence. On the contrary, it is precisely because such a linkage is all too plausible and probable that it is thought that there should not be included in our written Constitution any generalized guarantee of judicial independence. For the separation of powers principle-even the modest version of it which has been in vogue in Canadian constitutional law since the John East case of $1949^{17}$ - is a test of constitutionality which can well be done without. In applying such a test to a statute, Professor Lederman, who of all the commentators has been most sympathetic to this particular constitutional tradition, maintains that the courts would be doing nothing more than searching for "the answer of the reasonable man in modern circumstances about the desirability of superior-court administration of

14 O. Martineau and Sons Ltd. v. City of Montreal, [1932] A.C. 113, 121.

15 Toronto Corporation v. York Corporation, [1938] A.C. 415, 427 and 426.

16 Some of the consequences of this practice are discussed in Beasley, The Exercise

of "Judicial Power" in the Commonwealth of Australia (1949), 27 Can. Bar Rev. 686.

17 Labour Relations Board of Saskatchewan v. John East Iron Works Ltd., [1949] A.C. 134. 
the statute in question," and that the application of such a test "does not freeze either the provincial superior courts or the provincial noncurial tribunals to the actual or potential jurisdictional scope they respectively had in 1867." ${ }^{18}$ All this may be true but it does not make one any happier about constitutional provisions which invite the courts to apply even this pragmatic and relatively concrete test to provincial (or federal) administrative schemes. For it is still an institutional test; it gives constitutional recognition to the value of having a particular type of institution-a tribunal with the distinguishing marks of an English superior court-perform a particular range of functions. But is this a value which we really wish to enshrine in our Constitution? Is it regarded as essential that superior courts with judges enjoying constitutionally protected tenure determine a person's liability to municipal assessment, ${ }^{19}$ or decide in the first instance whether an employer is subject to a Labour Relations Act? ${ }^{30}$ The primary concern in these situations is surely not that a particular institution apply a particular part of the law, but that the law be applied in a particular way. The real value that we should attempt to secure is that, where a person's rights and interests are affected by a law-applying decision of a public authority, this decision is made as fairly and as impartially as possible. It is submitted that this value of procedural fairness and impartiality in the application of laws is the underlying normative basis for the importance which our constitutional traditions have given and still give to judicial independence. But the trouble with securing this value by so cumbersome a device as a constitutional guarantee of judicial independence is that such a vehicle for judicial review is apt to secure both too much and too little. Too much, because of the possibility it opens up for vetoing administrative schemes not because they are unfair or partial, but simply because they are not carried out by curial institutions; too little, because administrative practices which may well violate our norms of fair procedure might easily pass the separation of powers test.

The constitutional guarantee of judicial independence and the separation of powers it necessarily implies belong to an earlier era of political conflict and an outmoded style of political theory. There may have been a time when the citizen's freedom from arbitrary and capricious government was in serious jeopardy because of governmental coercion of judges, but that time is not now. In recent decades the citizen's wellbeing has been much more seriously threatened by the judiciary's resistance to the novel administrative schemes of the expanding welfare-state. The retention or expansion of a constitutional guarantee of the tenure and salaries of superior court judges might seem a harmless enough gesture to the political victories of yore, were it not for the fact that it would give a constitutional sanction to this particular exercise of judicial activism, which already finds sufficient outlets through statutory interpretation and the aggressive application of the common law's prerogative writs. ${ }^{21}$ Furthermore, a guaranteed role in law applying for superior

18 Op. cit. supra, n. 4, at 1172.

10 See, for instance, Toronto v. Olympia Edward Recreation Club Ltd., [1955] S.C.R. 454.

$20 \mathrm{As}$ in $R$. v. Ontario Labour Relations Board, ex parte Ontario Food Terminal Board (1963), 38 D.L.R. (2nd) 530 .

21 Professor Willis gives a succinct description of these various non-constitutional bases for judiclal review of administrative action in Administrative Law and the British North America Act, op. cit. supra, n. 13, at 274-281. For an indication of the Supreme 
courts, Professor Lederman's protest notwithstanding, involves a static conception of the "judging" function which is at odds with both contemporary jurisprudence and political science. It is very doubtful whether the effort to evolve an operative definition of a "judicial function" which has been so abortive in administrative law would be any more succesful when applied to the task of establishing in Canadian constitutional law a clear test of the functions of an English-superior court. At the same time, western political science has been following a path parallel to that of administrative law and is now in the throes of abandoning an institutional conception of governmental processes in favour of an approach which conceives of any given institutional structure as carrying out a number of functions, including those which have traditionally been regarded as the functions of judges. ${ }^{22}$ From the perspective of this structural-functional mode of analysis, the attempt to ensure through the Constitution that a particular range of law-applying functions is performed exclusively by particular curial institutions is truly an impossible dream. Only those who still believe that the multifarious functions of government can be neatly assigned to the classical legislative, executive and judicial divisions of power can continue to believe in the efficacy or wisdom of constitutional provisions for the separation of powers. As time goes on, the ranks of those who can subscribe to such a faith, even among the judiciary, will likely diminish.

What these future generations of Canadians may appreciate much more than a constitutional guarantee of judicial independence is explicit constitutional recognition of those procedural norms which are deemed to be essential elements in the fair application of laws. If some provision is sought to be made in our Constitution for the fair and impartial application of laws, we should look in the direction of constitutional guarantees of "legal rights" along the lines of section 2 of the Canadian Bill of Rights or Chapter III, section 2, of the recently proposed "Canadian Charter of Human Rights." 23 The selection of the particular rights which should be given constitutional status and their exact formulation are tasks which require much more careful attention than they have as yet received. Nevertheless this is the most direct and effective way of establishing those constitutional values which constitute the underlying normative basis of our interest in maintaining an independent and impartial judiciary.

It should be emphasized that the argument advanced here is directed not against giving senior Canadian judges office on good behaviour and freeing their salaries from dependence on annual parliamentary votes; it is directed only at entrenchment of these arrangements in the written Constitution. Nor need we shudder at the prospect of having judicial tenure and salaries protected by nothing more than ordinary statutes. Statutory provisions seem to have provided adequate protection for the independence of English judges and for our own federal judges. Paradoxically, the one aspect of judicial independence which requires constitutional protection-the tenure of judges of the Supreme Court of

Court's leanings in this direction in more recent times see L'Alliance des Professeurs Catholiques de Montreal v. Labour Relations Board of Quebec, [1953] 2 S.C.R. 140 and Cutler, The Controversy on Prerogative Writs (1963), 23 La Revue du Barreau 197.

22 The manifesto of this approach in political science is the Introduction to Almond and Coleman. The Politics of the Developing Areas (1960).

23 Trudeau, A Canadian Charter of Human Rights 19-24 (1968). 
Canada-is not now clearly provided for in the B.N.A. Act. There is a particularly strong case for providing in the Constitution that the members of the tribunal, whose primary function it is to have the final word in applying the Constitution to all citizens and both levels of governments, should, once appointed, be as independent as possible of all other governmental agencies. Constitutional provision for the security of Supreme Court judges' office and salary would be mainly of symbolic importance as part of a general constitutional reconstruction of the Supreme Court's position (to be further discussed below) designed to alter the court's constitutional status from that of an agency of the federal government to a creation and instrument of the Constitution itself. Such a provision, besides guaranteeing tenure on the conditions now set out in section 9 of the Supreme Court Act, might also prohibit any diminution of the judges' salaries while in office and fix the number of judges who can serve on the Court at any one time. So long as this clause were specifically and exclusively applied to the Supreme Court of Canada, it would be a "safe" provision in the sense that it would not create the undesirable opportunities for judicial review which are apt to stem from a generalized guarantee of judicial tenure.

The inclusion in the Constitution of a guarantee of the Supreme Court judges' term of office may seem to point logically to the inclusion of a guarantee of the one essential component of the Supreme Court's jurisdiction-the enforcement of the Constitution. Indeed, may it not be necessary to give constitutional recognition of the general responsibility of courts for applying the Constitution to the other branches of government? Does not this concern suggest that in one respect at least our Constitution should establish a basic "judicial residue"? I do not think so. Judicial institutions in general-federal or provincial-should not be put alongside elected legislatures as one of the primary constituent elements in the Canadian system of government. While it is realized that this is a rather sweeping negation, it is not nearly as earth-shaking as it may sound. For Canadian judges, following the example of their English peers, have not relied on the provisions of any written Constitution to defend their jurisdiction, to stretch and create remedies or to side-step clauses in legislation aimed at excluding their review of administrative practices. As a practical matter it is the courts themselves which have the last word in deciding whether or not a controversy is judiciable, and it is submitted that they can be relied upon to preserve an adequate domain for themselves without any assistance (or encouragement) from the written Constitution. Still some may feel that the Constitution should guarantee the citizen's right to have the constitutionality of laws to which he is subjected determined finally by courts, especially if the Constitution provides no general guarantee of curial control.

I do not think we should go very far to meet this concern. Already, without any constitutional clause explicitly securing judicial review of the constitutionality of legislative and executive acts, the Canadian courts have dismissed governmental attempts to exclude judicial determination of the constitutionality of their activities. Canadian jurists, with or without a general guarantee of judicial independence, are likely to agree with Mr. Justice Masten that the logic of constitutional government is such that: 
The legislature cannot destroy, usurp or derogate from substantive rights over which it has no jurisdiction by the Canadian constitution, and then protect its action in that regard by enacting that no action be brought in the courts of the province to inquire into the validity of its legislation, this indirectly destroys the division of powers set forth in the B.N.A. Act. In other words, it cannot by such indirect means destroy the constitution under which it was created and now exists. ${ }^{24}$

While, as is suggested below, the Constitution should positively declare the Supreme Court's role as the final court of appeal on constitutional and federal matters, such a declaration should not be worded so as to create a constitutional right to take constitutional questions before the Court. An entrenchment of the right to appeal to the Court would be extremely detrimental in that it would remove the minimum degree of control which the Court and the federal legislature must exercise over the Court's docket. It is preferable to risk the possibility that some Canadian judges might be so obtuse as to consider that the Constitution authorizes its own destruction by upholding a privative clause which precluded any judicial determination of constitutionality. One addition which might be made to the Constitution to bolster judicial insistence on enforcement of the Constitution is a supremacy clause, a clear declaration that the Constitution is the supreme "law of the land" binding on all judges, federal and provincial. A supremacy clause coupled with a clause declaring the Supreme Court's power to adjudicate constitutional disputes is the only provision which the Constitution should make for a residue of judicial power existing independently of all legislative power. Lawyers cannot be reminded too often that in the final analysis the power of courts to make authoritative determinations of disputes concerning important social values depends not on the words which appear in legal texts but on the support which opinion in the polity gives to the settlement of such controversies by adjudicative methods. In Canada, as in the United States, it is the public's preference for judicial determination of constitutional controversies which is the effective "guarantee" of judicial review. ${ }^{25}$

\section{BILINGUALISM AND BICULTURALISM}

Bilingualism and biculturalism, in the sense that these concepts connote a recognition of the historic duality of Canada's culture, form an essential element in the Canadian political ethic. This principle of cultural duality ought to receive adequate recognition in the Constitution. The question here is the way in which it should be incorporated into those parts of the fundamental law which deal with the judiciary.

\footnotetext{
24 Ottawa Valley Power Co. v. Attorney-General for Ontario, [1936] 4 D.L.R. 594, 605.

25 On this point American experience is instructive. In the Constitution of the United States the appellate Jurisdiction of the Supreme Court is subject to "such exceptions, and under such Regulations as the Congress shall make." In Ex Parte McCardle (1869) 7 Wall. 506, the Supreme Court held that this clause entitled Congress to remove the Court's appellate jurisdiction in habeas corpus cases. The aim of this legislation was to prevent the Court from considering the constitutional validity of some of the Reconstruction measures which had been challenged in habeas corpus proceedings. But this legtslation ruled out only one remedy whereby judiclal review might be But this legislation ruled out only one remedy whereby judiclal review might be
involked. There is considerable doubt as to Congress' power to enact legislation which would effectively prevent the Supreme Court from applying a particular part of the Constitution. See, for instance, Hart, J. and Wechsler, The Federal Courts and the Federal System, 312-313 (1953). There was a movement in Congress to enact such lgeislation in the 1950's and again this year. See Graham, New York Times, Sunday, April 28, 1968. But the Supreme Court Itself will have the last word in determining the constitutional validity of this legislation, so long, that is as the effective political forces in the country permit the issue to be determined by adjudicative processes.
} 


\section{Bilingualism}

In so far as the first of the B's is concerned, there are no grave problems involved in making adequate provision for bilingualism in the judicial provisions of the Constitution. The main reform to be adopted is that which has already been proposed in Book 1 of the Report of the Royal Commission on Bilingualism and Biculturalism. ${ }^{26}$ The proposal there is essentially to extend to the Superior Courts of New Brunswick and Ontario the right which section 133 of the B.N.A. Act already gives to any person to use English or French in any pleading or process in or issuing from any Court of Canada or any of the Courts of Quebec. The full amendment to section 133 which the Report proposes also contemplates the extension of this right to the Superior Courts of any additional provinces where the composition of the population eventually calls for the adoption of a bilingual régime, and similarly to bilingual districts which may be established in other provinces. Two of the Commission's other recommendations, the Commissioner of Official Languages, a sort of "linguistic ombudsman" and Official Languages Acts, would also enhance the citizens' linguistic rights in judicial proceedings. ${ }^{27}$ However the right to an interpreter, included in the latter proposal, might more appropriately find its place in a Constitutional Bill of Rights. ${ }^{28}$

It should be noted that in one respect the suggested amendments to section 133 constitute a diminution rather than an expansion of the constitutional mandate for bilingualism in judicial proceedings. For Quebec it confines the right to use French or English to the Superior Courts, whereas the section new applies that right to "all or any of the Courts of Quebec." It can be assumed that the Commission's reasoning here was that it would be unfair for the Constitution to impose the use of English and French on the lower courts of Quebec, so long as it was impractical to require this of the other officially bilingual provinces.

But this section of the Constitution might give rise to a more serious problem. That is it might open up the very possibility for judicial review which it was earlier urged should be avoided by narrowly restricting the Constitutional guarantee of judicial independence. Judges might consider that a constitutional right to use either of the official languages in the "Courts of Canada" or the "Superior Courts" of officially bilingual provinces implied that these courts must have preserved to them a certain guaranteed minimum of jurisdiction. Otherwise a province (or the federal government) could render this right useless by transferring to other tribunals many of the adjudicative tasks normally undertaken by these courts. Thus section 133 might replace section 96 as the constitutional basis for the judiciary's application of a division of powers doctrine to federal and provincial administrative schemes. Admittedly such a development is possible, although not nearly as probable as is the derivation of a separation of powers concept from an enlarged constitutional guarantee of judicial independence.

But it is important to see why we can more readily accept the possibility of judicial derivation of a separation of powers doctrine from a constitutional requirement of bilingualism than from a constitutional guarntee of judicial tenure. In the latter case the key test of a "court"

28 Report of the Royal Commission on Bilingualism and Biculturalism, Book I, 125 (1967).

28 The right to an interpreter is now included as Section $2(\mathrm{~g})$ of the statutory Canadian Bill of Rights, and in the proposed Constitutional Charter of Human Rights. 
which must be met by a tribunal carrying out the guaranteed curial function is that it be manned by officials holding office on good behaviour and removable only by an elaborate and difficult process. To meet this test, officials who might be deemed to be making judicial decisions or the kind of decision normally made by a superior court would have to be appointed for life, or at least until age 75 . This is a very undesirable constraint to impose on provincial or federal administrative arrangements. If, however, a separation of powers doctrine were invoked in the name of protecting the bilingualism secured in section 133, this would logically require only the extension of bilingual rights to proceedings before quasi-judicial or judicial administrative tribunals. Already there are "indications that both federal and Quebec boards and commissions as a matter of practice give varying recognition to the right of Frenchspeaking or English-speaking citizens to use their mother tongue."29 It would surely not be regrettable if an activist judiciary were to push this tendency a little further and a little faster.

The Royal Commission was wise to preface its constitutional proposals by pointing out that ". . . constitutional provisions regarding the use of official languages, as contrasted with official language acts, should be general in character and cannot and should not attempt to resolve all the problems involved in formally recognizing the two languages."3o For it must be recognized that even an expanded section 133 can establish only the minimal symbolic recognition of bilingualism which a constitution can provide. There are many more tangible measures which must be taken at the legislative and administrative levels to make it as easy for Francophones to exercise their language rights "guaranteed" in section 133 as it is for Anglophones.

In examining bilingualism in the Supreme Court for the Royal Commission, the writer discovered what many French-speaking counsel have been finding out since that Court's establishment-that if they wished to maximize their chances of winning their case they should not exercise their right to plead in French. ${ }^{21}$ For a French-speaking lawyer usually argues his cases before a panel of judges, a majority of whom cannot follow him in French. Some might contend that the only way to rectify this situation is by means of a constitutional or statutory requirement that cases conducted in section 133 courts be heard by judges fluent in the official language being spoken. But this would certainly be the wrong way to make bilingualism operational in the Supreme Court, or the other section 133 courts. A requirement that judges be bilingual would impinge far too severely on the recruitment process, which is already difficult enough, especially for the senior federal courts in Ottawa. ${ }^{32}$ If such a requirement were made mandatory by the Constitution or statute, it conjures up the possibility of one of the most embarrassing kinds of litigation-the request that judges review their colleagues' qualifications for office.

29 Op cit. supra, n. 26, at 61 .

80 Id., at 134.

81 The results of this study are reported in the author's Bilingualism and Biculturalism in the Supreme Court of Canada, ch. III, section 2, to be published shortly by the Queen's Printer, Ottawa.

32 The difficulties of recruiting good lawyers for the bench has been frequently commented upon in Parliament, particularly by federal Justice Ministers. See, for instance, Sir Charles Fitzpatrick (1903) 62 H.C. Deb. 10769; Louis St. Laurent (1944) H.C. Deb. 5234; and Davie Fuiton (1962) H.C. Deb. 2395. Some of the principal recruitment problems are analyzed in Biggar, The Selection of Judges (1933), 11 Can. Bar Rev. 27. 
On the other hand, a bilingual bench might be achieved simply by appointing a sufficient number of judges from each language group to ensure that a judge or panel of judges, proficient in the official language chosen for use by the parties, was available for every case. Such a practice might be viable for trials in the provincial superior courts, the Exchequer Court of Canada and even possibly for proceedings before the provincial appeal courts where the required quorum does not constitute a large fraction of the court's total personnel. Still, as a constitutional or statutory requirement, it is submitted that it would unduly rigidify the management of these courts. But it would be completely unacceptable for the Supreme Court of Canada to be required to adhere consistently to such a practice. As the nation's highest court of appeal, it is particularly important that the Supreme Court bring to bear the experience and judgement of all its members on the important legal questions brought before it. Insistence on linguistic purity here would necessitate the adoption of a panelling system which would seriously impede the growth of that Court's collegiality. ${ }^{33}$ Nor would such a panelling system be any more desirable in the guise of fixed English common law and French Civil Law chambers of the Court. Undoubtedly the Court majority's inadequacy in French adversely affects the Court's capacity for developing a civilian jurisprudence. But, as is argued later, the proper solution to that problem is not a Civil Law Chamber of the Supreme Court but a curtailment of appeals to that Court in Civil Law matters. All this is not to argue against giving close attention to the linguistic abilities of judges in making appointments to the bench or in distributing a court's work-load. It is only to suggest that a genuine bilingualism is not to be achieved by making these practices mandatory.

The more effective and less troublesome approach to curial bilingualism is to increase the court's linguistic services. The most obvious need is for the translation of oral arguments and written briefs, both of which services are provided in the International Court of Justice at Le Hague. ${ }^{34}$ These facilities are particularly needed in the Supreme Court of Canada, where several of the English-speaking judges are always likely to lack a mastery of French. That Court's bilingual capacity would also be substantially enhanced by attaching French-speaking law-clerks to the Court's English speaking justices; the consequences of its linguistic short-comings could be mitigated by reducing the relative importance of oral arguments in its proceedings; and the opportunities of lawyers and citizens of both cultures to share its jurisprudence would be considerably increased by publishing all of its decisions (head-notes and opinions) in both of the official languages. It might be necessary to effect some of these procedural reforms by means of legislation if the section 133 courts failed to act quickly or effectively enough. The power of Canadian judges to establish the rules of their courts is one of the most consequential and least noticed instances of delegated legislative power in our system of

33 It is particularly important, as Professor Laskin has argued, “. . . that the full bench must sit in all constitutional cases." Laskin. The Supreme Court of Canada: a Final Court of and for Canadians (1951), 29 Can. Bar Rev. 1038, 1044. Between 1949 and 1965 the full court sat for only 45 per cent of the (reported) constitutional cases. See Table 3 in the study referred to in $\mathrm{n}$. 31 .

34 At Le Hague, where French and English are the official languages of the Court, the Registrar prepares unofficial translations of written materials for the use of the Court and the parties when the parties elect to plead in different languages. Written translations of oral arguments are prepared and distributed throughout the hearing. See Shabtal Rosenne, The International Court of Justice (1957). 
government. This is acceptable so long as the rules legislated by judges are not noticeably at odds with broad public policy. It is worth recalling that some years ago the Supreme Court of Canada deleted from its rules the provision that permitted a judge to compensate for his linguistic inadequacy, at the litigant's expense, by having the factum or judgment below "translated into the language with which such judge is most familiar." ${ }^{35}$ The Supreme Court's failure now to replace such a rule with procedures, which, at the public's expense, will encourage citizens to exercise their rights under section 133 , should certainly prompt action by the federal parliament, or the Commissioner of Official Languages if such a position is established.

\section{Biculturalism}

Turning now to the other B, Biciulturalism, it is very difficult to see how this concept, as a separate and distinct dimension of our historic dualism, can be translated into working principles of government. This is generally true for all aspects of the constitutional system, and particularly true for our judicial arrangements. There is, to be sure, a markedly dualistic element in the Canadian legal culture: there are in Canada two systems of law governing private civil rights, the codified Civil Law derived from French and Continental sources, and the English common law. But the Civil Law system adheres not to all of French Canada but only to Quebec, and there it is, of course, as much the legal system of the non-French minority as it is of the Province's Frenchspeaking residents. Thus, although historically the Civil Law has constituted one of the most significant elements in the French culture in Canada, operationally (since 1791) it has existed strictly as a provincial phenomenon. For this, and other reasons, it is submitted that it should be treated as a provincial right under our federal system and not as an integral element of our national courts.

It is as a provincial right that the integrity of Quebec's Civil Law is now protected in the B.N.A. Act. The prime reason for including the all important matter of Property and Civil Rights in the provincial list of legislative powers was to enable Quebec to preserve her distinctive system of private law. For the same reason Quebec was excluded from the scope of section 94 which contemplated the eventual assimilation of the laws relating to property and civil rights in the common law provinces. Most significantly, section 98 required that the judges of the Courts of Quebec should always be drawn from the Bar of that Province, whereas section 97 lifted such a requirement for the other provinces once their systems of private law had been assimilated. But there was one nearly fatal gap in the Constitutional protection afforded Quebec's Civil Law and that was the plenary appellate jurisdiction which section 101 empowered the federal parliament to vest in a General Court of Appeal. At the time of Confederation and for several decades afterwards, a number of Quebeckers vigorously resisted granting a federal Supreme Court the power to review the Civil Law decisions of Quebec courts. ${ }^{30}$ In their view the exercise of such an appellate jurisdiction by a Supreme Court, in which civilian jurists constituted a minority,

\footnotetext{
35 This was provided for in the original rules of the Court, Rules 64 and 65 . Cassels (ed.), Manual of Procedure in the Supreme and Exchequer Court of Canada (1877). 86 This movement is described and documented in Chapter $I$ of the study referred to in n. 81 .
} 
meant not only that the decisions of Quebec's civilian judges would be subject to review by a technically less competent appeal court, but also posed a serious threat to the integrity of Quebec's system of Civil Law. This complaint has echoed in vain down through the years. It has been pressed with increasing vigour in the past decade. And it seems that it is as valid a case to-day as when it was first put forward by Joseph Cauchon, Antoine Dorion and Henri Taschereau in the Confederation debates. ${ }^{37}$

The merits of this case cannot be examined here, except to point out in passing that aside altogether from its strictly jurisprudential aspects, the prime basis for honoring this claim is political. It is after all a claim for judicial autonomy in matters of local concern, and as such no more dependent on its technical merits than was the larger Canadian claim for judicial autonomy from Great Britain. What must be decided now is the best way of meeting this demand. The choice must be made between two basic approaches-the establishment of an adequate civilian chamber in the national court of appeal or giving Quebec the opportunity to establish the highest provincial court as the last court of appeal in Civil Law matters. It is the latter approach which the writer favours, not just for Quebec but for all the provinces. The grounds for this preference have primarily to do with my view of the proper place of federalism in our judicial system and the proper role of the Supreme Court. These arguments will be set out in the final section of this paper.

But before turning to the federal elements in the judicial system, there is one other bicultural claim which must be considered-the proposal of a binational Supreme Court. Professor Jacques-Yvan Morin, for one, has advocated that a national court for the adjudication of constitutional issues be composed of an equal number of jurists from English and French Canada. ${ }^{38}$ This proposal should be resisted on two counts. First, it would be a mistake to establish a system which required all constitutional disputes to be separated from the main stream of litigation and decided in isolation from the other legal issues with which they are likely to be intertwined. Dean Ledain has convincingly demonstrated how inappropriate it would be to superimpose such a system on the pattern of constitutional litigation and jurisprudence which has evolved in Canada. ${ }^{39}$ His arguments are all the more persuasive when one contemplates the holocaust of constitutional litigation which is likely to follow upon the entrenchment of a vast Bill of Rights in the Canadian Constitution. American experience, as well as our own with the anemic Diefenbaker Bill of Rights, reveals how frequently in the course of litigation counsel will resort to such a codification of political or procedural norms. A Constitutional Court which was required to adjudicate all such claims in their naked form, disassociated from all other components of the cases in which they arose, would propel such a tribunal into the role of an extremely active yet ethereal super-legislature. And, as we may soon come to appreciate, the enforcement of a constitutional Bill of Rights, unlike the application of a federal division of powers, can leave both levels of government powerless.

87 See their speeches on this question in Parliamentary Debates on the Subject of the Confederation of the British North American Provinces 575, 690 and 896 (1865).

38 Confederation of the Brit

39 Ledain, Concerning the Proposed Constitutional and Civil Law Specialization at the Supreme Court Level (1967), 2 La Revue Juridique Thémis 107. 
The second and more pertinent objection is to the whole idea of treating biculturalism as if it required French-English numerical equality in our national institutions. This theory is particularly noxious when it is applied to the federal Supreme Court. The adjudicative functions of this Court are such that its members should not be defined as representative of the two major cultural groups in Canada. The great array of legal issues which come before the Court, in constitutional, commercial, criminal, and other branches of public law do not have distinctively English-Canadian or French-Canadian solutions. The Supreme Court, no more than any of the other branches of our national government, should not be designed as if its major purpose were to arbitrate the differences between French and English Canada. The prime function of that Court should be the development of a jurisprudence, relative to those legal concerns which are of national concern, which can be shared equally by French and English-speaking citizens and which is appropriately sensitive to all of the country's major social values including biculturalism.

\section{FEDERALISM}

There are two reasons for seeking to bring a larger measure of federalism into the Canadian Constitution. The first is that as a matter of practical politics federalism is the constitutional orientation which is best able to satisfy the conflicting hopes and fears which agitate Canada's political system today. Federalism comes much closer to meeting the common denominator of the constitutional expectations of Canadians than do either of its two main alternatives-a more centralized form of government or binationalism. The former of these is as unacceptable to French-speaking opinion in Quebec as the latter is to opinion outside Quebec. Thus federalism provides the most integrative formula for constitutional statecraft in Canada today.

This proposition was probably valid for the Canadian nation-state of one hundred years ago. But a second factor, not present in 1867, makes it both mandatory and appropriate today to incorporate federal principles much more thoroughly in the Canadian Constitution-that is the simple fact that we have now had a century's experience in the art of federalism. As a nation, we have learned how to operate a federal state, to the point where we need no longer regard federalism either as an unfortunate concession which devotees of a unitary state must make to a transient parochialism, or as the last ditch defence of an embattled ethnic minority against the assimilating aspirations of the national majority. As political entities, the provinces have come of age, rivalling Ottawa with the talent of their governmental systems and the interest their projects arouse in the electorate. At the federal level, the Imperial mechanisms of control over the provincial executives and legislatures have been abandoned. No longer can a federal politician or a federal judge refer to the provinces as mere municipalities not to be fully trusted with the instrumentalities of government. Such an attitude today would not only be out of keeping with the facts of Canadian government, but would violate the country's predominating political ethic. For we have come to see that the task of distributing governmental functions so that matters of common national concern are dealt with federally, while those 
to which distinctly local interests attach are handled by governments responsible to local electorates, is not an inconvenient but an ideal possibility. In this sense federalism has become, as it was not in 1867, a positive political value.

The shortcomings of the Constitution in terms of this value are nowhere more evident than in the provisions which the B.N.A. Act makes for a judiciary. Sections $92(14)$ and 101 give to the provinces and the federal parliament respectively the power to establish their own courts. ${ }^{40}$ But this division of power over the judiciary is overbalanced by sections 96, 99 and 100 and a further implication of section 101, which, together, give federal authorities a plenary control over both the personnel and the jurisprudence of the provincial courts. ${ }^{11}$ The power which section 96 vests in the Governor-General to appoint the judges of Superior, County and District Courts in the provinces reflects the conceptions which imperial and colonial statesmen had of executive power flowing from a single indivisible source of sovereignty. ${ }^{42}$ (Ironically, it was the highest court of the Empire itself which was later to teach Canadians that federalism involved the operation of dual sovereignties.) ${ }^{43}$ And although section 100 of the Constitution placed the burden of paying the provincial judiciary on the federal treasury, to the Canadian politicians of the day this must have seemed a small enough price to pay for retaining monopoly over such an important source of patronage.44 Section 101, which, by virtue of judicial construction, gives the federal parliament an overriding power to vest appellate jurisdiction over the decisions of provincial courts in the Supreme Court of Canada, is consistent with the scope of appellate authority which the Imperial Privy Council exercised over the administration of justice in the British colonies. ${ }^{45}$ These elements of the Constitution, premised as they are on outmoded precepts of imperialism and monarchy, must now give way to arrangements which are more compatible with federalism.

40 The federal Parliament's power to establish courts is more limited than that of the provincial legislatures. Its power under section 101 to provide for "the Establishment of any additional Courts for the better Administration of the Laws of Canada" has been so construed as restricting the original jurisdiction of federally created courts to legal matters which are subject to federal legislative authority. Consolidated Distilleries Ltd. v. The King, [1933] A.C. 508 .

41 Since under section 101 the federal parliament has been able to give the Supreme Court the power of reviewing the decisions of provincial courts in provincial as well as federal law matters, the provincial appeal courts are bound to follow supreme Court decisions on provincial law issues. Mark MacGuigan has recently pointed out that "Whatever their attitude towards English authorities, provincial courts, by and large, have been assiduous in refraining from any encroachment on the scope of Supreme Court of Canada decisions." MacGuigan, Precedent and Policy in the Supreme Court (1967), 45 Can. Bar Rev. 627, 643.

42 According to $\mathrm{E}$. M. Macdonald, ". . ' the only reason why the appointing power was vested in the Dominion Parliament was the theory that the Governor-General was the sole representative of His Majesty in Canada." (1922) H.C. Deb. 429. While this overstates the importance of the single sovereignty theory, early constitutional litigation indicates widespread support for this conception. This can be seen in the field of judicial power in early cases challenging the provinces' power to appoint minor judicial officers such as fire marshalls and magistrates: R. v. Coote (1873). L.R. 4 P.C. 599; Ganong v. Bailey (1877), 1 P. \& B. 324; R. v. Bush (1888). 15 O.R. 398.

43 See the Judicial Committee's decision in Maritime Bank v. Receiver General of New Brunswick, [1892] A.C. 437.

44 In the Confederation Debates, the Honourable John Rose cited the judicial patronage reserved for the federal government as one of the key advantages of the constitutional scheme. Op. cit. supra, n. 37, at 387. Hector Langevin provided the only sustained defence of federal control over the appointment of provincial judges. According to him the main advantage of such a system was that it would keep off the bench the "troublesome advocate of the second, third or fourth order of talent" who was likely to have a great influence on the local legislature. Id., at 387-8.

45 The Privy Council's decision in 1947 declaring the Dominion's "plenary authority to legislate in regard to appellate jurisdiction" assumes that a centralized system of judicial control is the norm for any "fully sovereign state." "It is," said Lord Jowitt. "a prime element in the self-government of the Dominion, that it should be able to secure through its own courts of Justice that the law should be one and the same for all its citizens." A.-G. Ont. v. A.-G. Canada, [1947] A.C. 127, 137. 
It would no doubt be wrong to make a fetish of federalism by insisting that the division of judicial power exactly parallel the division of legislative power. The important modification of such a thorough-going duality in our judicial structure which should be retained is the combining of jurisdiction over both federal and provincial laws in the provincial courts. ${ }^{40}$ This aspect of our judicial system means that when the citizen commences an action, or seeks to appeal the judgment of the trial court he does not have to decide to which set of courts-local or federal-he can or should resort. ${ }^{47}$ In this respect our judicial structure should remain unitary and avoid the unnecessary confusion and duplication which arises from the existence of dual judicial systems in the United States and (in a more modified form) in Australia. ${ }^{48}$ The suggestions which are made here for the increased federalization of the judicial provisions of the Constitution are perfectly consistent with the continued integration of provincial and federal jurisdiction at the primary level of the administration of justice. Nor are they designed to serve the ends of federalism at the expense of the efficient administration of justice. On the contrary, while they may introduce some new jurisdictional complexities, they will remove other difficulties and secure some real advantages for judicial management.

The case for giving the provinces the right to appoint the judges of provincial courts by no means rests solely on grounds of federalism. It is a reform which would also contribute substantially to more responsible management of the provincial judicature. Under the Constitution as it now stands, before a province can implement changes in its judicial system requiring additional County, District or Superior Court judges, or changes in the provincial circuit system or in the distribution of labour among the judges, the federal parliament must amend the federal Judges Act $^{40}$ to provide for the additional salaries, the changes in travelling allowances, or judicial positions which the provincial legislation may require. But while the federal parliament has the exclusive power to provide for these aspects of the provincial judicature it has no responsibility for the establishment and administration of the provincial courts, which under section $92(14)$ of the B.N.A. Act is the exclusive concern of the provinces.

It is a tribute to the ingenuity and good will of federal justice ministers and provincial attorneys-general that under such a ludicrous system, which Laurier once called a "strong defect"so and on another occasion a "failure" 31 in our Constitution, we have been able to stumble along as long as we have. But it has certainly promoted a stumbling kind of performance in the administration of provincial courts. At first, under

16 The prime basis for the federal parliament's explicit vesting of federal jurisdiction in provincial courts was established in Valin v. Langlois (1880) 3 S.C.R. 1 and in In re Vancini (1903-1904) 34 S.C.R. 621. If no other mode of enforcing a federal law is established, the provincial courts are assumed to have jurisdiction to enforce it. Board v. Board, [1919] A.C. 956.

47 Except, of course, where the federal legislature has established federal courts of original jurisdiction such as the Exchequer Court of Canada.

48 One of the main reasons for the dual system of courts or dual jurisdictions provided for in the constitutions of these federations was the desire to insulate suits between citizens of different states from local bias by vesting a diversity jurisdiction in federal courts. The need to reconsider this jurisdiction has been expressed in both countries. courts. The need to reconsider this Jurisdiction has been expressed in both countries. 13 Law and Contemporary Problems 216, and Cowan, Federal Jurisdiction in Australia (1959).

19 Supra, n. 9.

80 (1898) 47 H.C. Deb. 6766

61 (1900) 53 H.C. Deb. 9114. 
Sir John A. Macdonald's easy-going ways, the policy of federal authorities was to grant provincial requests for more judges without questioning their necessity. ${ }^{52}$ But gradually, with the development of a substantial Justice Department in Ottawa, the federal government has come to take much more care in scrutinizing provincial requests. ${ }^{53}$ At times this has meant that federal intervention has blocked or frustrated the provinces in administering their judicial systems. Prince Edward Island, for instance, which in 1922 had made provision in its own judicature act for a fourth Superior Court judge so that it might have an effective appeal court, ${ }^{54}$ was not able to implement this reform until 1960 when the federal government was finally persuaded to effect the necessary amendment to the Judges Act. ${ }^{55}$ Or, to cite an instance of provincial testiness, Justice Minister Fulton reported in 1960 that Premier Smallwood of Newfoundland refused to proclaim a provincial act creating a new superior court judgeship until he was assured "as to the kind of appointment" the federal government would make to this new position. ${ }^{\text {so }}$

While there would seem to be much to be gained by abandoning this system of divided control over the provincial judiciary, is there anything to lose? The provinces will certainly lose some money. Although federal expenditure under the Judges Act constitutes a tiny fraction of the total federal expenditure (provincial judges' salaries cost the federal government about $\$ 8 \frac{1}{2}$ million in 1967), ${ }^{57}$ these sums might loom much larger in the budgets of the provinces, particularly the smaller ones such as P.E.I., where federal per capita expenditures on the salaries of provincial judges amounted to 96 cents in 1961 as compared with 20 and 21 cents in Ontario and Quebec respectively. ${ }^{58}$ However the judicial system is not the appropriate instrument for channelling transfer payments to the have-not provinces. If transferring responsibility for provincial judges' salaries to the provinces places an undue burden on any province, the remedy should be sought through the use of such fiscal mechanisms as the Equalization Grants.

82 The fullest statement of Macdonald's section 96 policy is given in (1880) 8 H.C. Deb. 118-120. But note that earlier in 1874 a Conservative majority in the Senate had rejected a bill acceding to Nova Scotia's request for county court judges. See discussion of this, id., at 120 .

53 The watershed period in this development was the prolonged parliamentary debate during the Laurier administration on the provision of additional superior court judges requested by Quebec. On this occasion it was the Conservative opposition that insisted on a close examination of the provincial request, including negotiations with Quebec officials to bring about reforms in that province's judicial system. Laurier at first
resisted these demands on provincial autonomy grounds. He maintained that the onus of proof was on the federal govenrment to show that the provincial request was unfounded. But he eventually came around to accepting the necessity of meeting with provincial officials and pressing for changes in the judicial system as a piecondition for granting the province more judges. For some of the highlights of this episode see: (1898) 47 H.C. Deb. 6734-80; (1900) 53 H.C. Deb. 10035-96; (1905) 73 H.C. Deb. 9740-97. Fairly typical of the approach taken by modern Justice Ministers is the explanation offered by Stuart Garson in 1950 for refusing to fill a judiclal vacancy in Alberta: "In accordance with our usual custom, we have asked the attorney-general to supply us with statistics showing the volume of litigation and indicating whether any congestion... is due to the fact that there has been a large increase in the volume of litigation or whether it is merely because of maldistribution of cases among the judges, so that some of them have far too much work while others do not have very much." (1950) H.C. Deb. 3933 .

s4 S.P.E.I. 1922, c. 6.

ss See (1946) H.C. Deb. 3731, (1946) H.C. Deb. $4255-56$ and (1960) H.C. Deb. 7367.

66 (1960) H.C. Deb. 7368.

57 This figure is based on the salaries and judgeships provided for in the Judges Act as amended up to the end of 1967.

68 These figures are derived from the salaries and Judgeships provided in the Judges Act as of 1961 and the population figures in the 1961 census. Note that the per capita expenditure on section 96 judges did not necessarily favour the poorer provinces: the figure for Newfoundland in 1961 was 23 cents, while British Columbla recelved 32 cents per capita. 
Elimination of section 96 will deprive the federal government of one of its handiest sources of patronage. The appointment of $\mathrm{Mr}$. Lawrence Pennell to the Ontario Supreme Court is simply the most recent (and perhaps, the least objectionable) instance of the usefulness of a vacancy on the provincial bench at the time of a federal cabinet shuffle. ${ }^{59}$ I suspect that, when the chips are down, this will be the real reason for the federal government's resistance to giving up control over the appointment of provincial judges. It should also be one of the main reasons why the rest of the populace should press for a change. For section 96 enables the federal political party which is in office in Ottawa to exercise a monopoly power over the final selection of all the senior judges in Canada. In appointing section 96 judges provincial governments would likely be as partisan as Ottawa has been. ${ }^{\circ 0}$ But this would still represent a broadening of the political and social interests which are influential in selecting Canadian judges. It would for instance make it much more possible for lawyers who have been active supporters of such parties as the N.D.P. or Social Credit to win judicial appointments. There is also the possibility that, when there is an opportunity for comparing the appointments made by different authorities, and when appointments to the provincial bench are made in the provincial capital instead of in distant Ottawa, the selection of judges will be subjected to closer public scrutiny.

Perhaps the strongest case for continuing some measure of federal control over appointments to the provincial courts is that under our unified judicial system, provincial courts are responsible for administering federal as well as provincial laws. Mr. Peter O'Hearn, for instance, in his constitutional scheme, would for this reason retain at least a federal veto power over the appointment of judges to the highest provincial courts. ${ }^{01}$ But control over the selection and remuneration of provincial judges is surely not the right way to attend to this legitimate federal concern. If the provincial judges' interpretation of federal laws embarrasses federal interests, the proper avenues for correction are the federal Supreme Court's review of provincial court decisions in federal matters, or ultimately legislative action by the federal parliament itself. Or, if the services available in provincial courts seem inadequate or unsuitable for administering some branch of federal law, again the proper remedy is for the federal government, as it has already done in a number of instances, to vest jurisdiction in federal tribunals. ${ }^{62}$

Sections 96, 99 and 100 should be removed from the Constitution and need not be replaced. There is no more need in the Constitution for specific directions as to how the provinces or federal government should

59 There have been numerous examples of this in Canadian history. For some indication of the different situations in which this device might be used see (1907) 79 H.C. Deb. 2212-26, where through charge and counter-charge Liberals and Conservatives recount how their opponents have used judiclal appointments for partisan purposes.

60 For an historical account of partisanship in judicial appointments see William Angus' paper on "Judiclal Selection in Canada-the historical perspective," read to the annual meeting of the Association of Law Teachers, Sherbrooke, June, 1966.

61 O'Hearn, Peace, Order and Good Government 123 (1964).

62 This may not be possible with regard to criminal law, where section 91 (27) expressly excludes criminal courts from federal competence, although Laskin states that this is overridden by the notwithstanding phrase in section 101. Constitutional Law 804 (2d ed. 1960). Section 57 of The Supreme Court Act gives the judges of the Supreme Court an original furisdiction to entertain habeas corpus petitions in cases arising under the federal criminal law. Atlhough the constitutionality of this provision has not been directly challenged in the courts, members of the Supreme Court have expressed doubts as to its validity. Taschereau, J. in Re. Sproule (1886), 12 S.C.R. 140, 240, and Rinfret, C.J., in Re. Storgoff, [1945] S.C.R. 526, 552. 
appoint, pay or remove their judges than there is for such directions as to the appointment of their other administrative officials. This negative counsel involves nothing less than the proposition that within their respective spheres of power, and subject to any overriding Constitutional Bill of Rights, federal and provincial government in Canada should adhere to the principle of parliamentary supremacy instead of the separation of powers. The reasons for avoiding a separation of powers in the Canadian constitution were put forward in the section of this paper dealing with judicial independence. It was there suggested that the only exception to this negative recommendation should be the establishment of a constitutional status for the Supreme Court of Canada. The implications of that proposal will now be considered.

Both in the popular imagination and in the view of most Canadian statesmen, the primary role of the national Supreme Court is to act as the final arbiter of the Constitution or the "umpire of the federal system." Given this conception of the Court's prime function, it does seem anomalous that the Court should appear in the Constitution to be so completely a creature of the federal government. Surely the referee's very position, his appointment and his power, should not depend entirely on the fiat of one of the contending teams. ${ }^{63}$ There is a compelling logic to this line of argument. But it should not be pushed too far. Here the point which must be borne in mind is that, no matter what is done to entrench the Court's status and free its personnel and jurisdiction from exclusive federal control, the Court must remain primarily an instrument of national government. The institutional loyalties and intellectual perspectives of a court situated in the national capital and charged with the dual responsibilities of supervising the application of federal and Constitutional law, will be and ought to be national and not local in their orientation. ${ }^{64}$ The task of Constitutional statesmanship here is to design provisions which will secure the provinces' confidence in the integrity of the Court without so bifurcating control over it that it is unable to act effectively as the nation's highest tribunal.

The first step is easy enough: to have a clause in the Constitution declare the Supreme Court's existence instead of empowering the Federal legislature to establish (and inferentially) dis-establish it. But such a clause will also have to make some provision for the composition and jurisdiction of the Court. As for the Court's composition, the need to secure the Supreme Court judges' tenure, and salaries, and possibly the size of the Court in the Constitution has already been touched upon. The method of appointing the Court's judges is a thornier question.

The basic requirement is to provide for the participation of provincial (or extra-federal) interests in the appointment process. With the exception of Australia (and Canada) this is the norm in other federations where the national supreme court acts as the final arbiter of the Constitution. ${ }^{05}$ Although there are almost as many ways of providing for this as there are federal constitutions, most of these could be reduced

68 For a recent popular expression of this viewpoint see the submission of Presse Etudiante Nationale to the Royal Commission on Bllingualism and Biculturalism, Submission 240-271, pp. 48-9.

64 See a discussion of this tendency in the United States Supreme Court, see Schubert, Constitutional Politics 364-5 (1960).

05 Although in India, Malaysia and Nigeria the central cabinet has the final word in the appointment of supreme court judges, it is required to consult certain bodies before making appointments. See R. L. Watts, New Federations: Experiments in the Commonwealth 286 (1968). 
to two general approaches: participation of the division of the federal legislature which is most sensitive to provincial interests in the appointing process, or direct collaboration of federal and provincial authorities in making appointments. The writer's inclination is towards adopting the former method for Canada. Such a system, following the American pattern, would require Senate concurrence in the federal executive's nominations. Clearly the merit of this procedure would largely depend upon reforming the Canadian Senate so that it more effectively represents provincial interests. Increasing provincial confidence in the Court's integrity, it should be noted, is by no means the sole advantage of such a system. An additional benefit is the increased public exposure it would give to the federal government's selection of judges. ${ }^{68}$ Parliamentary discussion of nominees, particularly when it is part of a ratification process, might possibly be a better check on bad appointments than the professional nominating boards usually favoured by lawyers. ${ }^{67}$

The writer's preference for this method over the more direct involvement of the provinces in the appointing process is slight. One way of implementing the latter would be the adoption of an amalgam of West German and Indian methods-a requirement that the federal executive confer with the Attorneys-General and/or the Chief Justices of the Provinces before making appointments. ${ }^{68}$ If it was felt desirable to clarify the power of the respective parties in this process, it could be provided that the federal government would make the nomination, while a majority of the provinces would have to ratify such nominations. A procedure such as this is certainly preferable to one which would "regionalize" the Court by establishing a quota of Supreme Court judges for each major section of the country, and require the federal government's collaboration with the appropriate provinces in filling each region's vacancies. ${ }^{69}$ This type of scheme would go much too far in the direction of fashioning the Court in the image of a representative legislature and unduly rigidify the recruitment process. Indeed, if the suggestion that the provinces be given the power to determine which court should have final appellate power over provincial law matters were accepted, I would not favour entrenching even the present statutory requirement that at least three of the Court's nine judges come from Quebec. ${ }^{70}$ The size of regional populations and litigation in the Court are likely to change drastically

(6) For a discussion of the educational value of this process in the Untied States see Mason, The Supreme Court from Taft of Warren 74-75 (1958). At present the opportunities for parliamentary discussion of judicial appointments in Canada are severely limited. The Chairman of the Committee of the Whole House once ruled that, "It is not permissible to discuss the character, the conduct or the background of a judge except by motion for impeachment." (1942) H.C. Deb. 5074.

67 Although these two methods of improving the selection of judges are by no means mutually exclusive.

68 Under West Germany's Basic Law, judges of the Supreme Federal Court are appointed jointly by the Federal Minister of Justice and a committee for the selection of judges consisting of the Land Ministers of Justice and an equal number of members elected by the Bundestag. Members of the Federal Constitutional Court are elected, half by the Bundestas and half by the Bundesrat.) Section 124(2) of the Constitution of India provides for consultation with judges of the Supreme Court and the High Courts in the States before the President appoints judges to the Supreme Court.

69 And certainly preferable to the awkward system suggested by Faribault and Fowler. in which, for each constitutional law case, an ad hoc panel of the Supreme Court would be formed from four Supreme Court judges and the Chief Justices of three provinces. Faribault and Fowler, Ten to One: The Confederation Wager 76 (1965). For an early discussion of the problems involved in assembling ad hoc Supreme Court panels for particular kinds of cases, see (April 3, 1882) Sen. Deb. 240.

70 R.S.C. 1952, c. 259, s. 6. Faribault and Fowler propose entrenching this clause, but they envisage the Supreme Court continuing to exercise a large appellate jurisdiction over Quebec provincial law. For such cases they also propose assembling ad hoc panels, on which Supreme Court judges would be augmented by judges from the Quebec courts. See articles 51 and 52 of their proposal. 
over time. It would be a serious mistake to entrench regional quotas based on current patterns. The one quantitative dimension of the Court which might be entrenched is the overall number of judges-a provision which would make court-packing more difficult.

But the Court's composition and methods of appointment, while of considerable symbolic importance, are far less relevant to its real power and function than is its jurisdiction. Here constitutional changes must be made with a very careful eye to their effect on the distribution of power in the Canadian federal system and the elucidation of the Court's role. As it stands now the B.N.A. Act fails both to define the Supreme Court's purpose or to divide judicial power. Section 101 simply empowers the federal parliament to establish a General Court of Appeal and in so-doing to override every other provision of the Constitution. This section must be replaced by one which gives a clear declaration of the Supreme Court's purpose and ensures that the power to regulate its jurisdiction is not inconsistent with the basic division of power in the Canadian federation. ${ }^{71}$

The declaration contained in such a section should indicate that the Court's purpose is to act as the nation's final court of appeal for questions concerning the Constitution and other questions of law which are of importance to the whole nation, and as the court for trying disputes among the provinces or between the provinces and the federal government. ${ }^{2}$ This declaration would not in itself establish the court's jurisdiction. Rather it would serve as a constitutional guide for both the federal legislature and the Supreme Court in developing the Court's jurisdiction. The need for flexibility and selectivity in determining which cases the Court hears is such that the scope of its jurisdiction should be a matter of statutory law rather than constitutional law. What is essential at the constitutional level is to establish a legislative authority for regulating the Court's jurisdiction which is compatible with the federal system at the heart of the constitutional plan.

One limitation should be attached to the plenary power which section 101 of the B.N.A. Act now gives the federal parliament over the Supreme Court's jurisdiction. This federal power should be made subject to the overriding power of provincial legislatures to vest final appellate jurisdiction in any provincial law matters in the highest provincial court.

This latter proposal could be regarded as the appropriate way of replacing Section 94 of the present Constitution. Whereas that section was designed for a constitutional system in which federalism was envisaged as a temporary stage in the evolution towards a more unitary state, this proposal is designed for a state in which federalism is to be a permanent and pervasive principle of the constitutional plan. Instead of providing an opting-in device such as Section 94 whereby provincial legislatures could have the federal legislature assimilate their laws, this

71 I have discussed the basis for these particular reforms much more thoroughly in The Jurisdiction of the Supreme Court of Canada: Present Policies and a Programme for Reform, Osgoode Hall L.J., The Supreme Court Review, 1968.

72 The latter part of this declaration is designed to remove any doubts about the federal parliament's power of vesting an original jurisdiction in the Supreme Court for the parliament's power of vesting an original jurisdiction in the Supreme Court for the Because federal legislators doubted that, under section 101, parliament could give Because federal legislators doubted that, under section 101, parliament could give vesting original jurisdiction in these inter-governmental disputes in the Exchequer Court subject to the provinces passing enabling legislation authorizing this jurisdiction. (1806) R.S.C., c. 140, 8. 32 . 
revision of section 101 would enable all the provinces to avoid any further assimilation of their laws by the federal judiciary.

On the analogy with section 94 , it might be contended that just as that section excluded Quebec from the process of assimilation projected for the other provinces, so also it is only Quebec which needs to be given the opportunity to escape the assimilating tendencies of the Supreme Court's appellate jurisdiction in provincial law matters. But, while Quebec admittedly might have the strongest reasons for exercising this right to judicial autonomy in the field of provincial law, other provinces, albeit to a more limited degree, may also wish to avail themselves of the advantages which might flow from vesting final control over the meaning of provincial law in the province's appellate court, ${ }^{73}$ particularly where the law leaves a relatively wide area of discretion to the judiciary. Just as Section 94 did not compel the common law provinces to assimilate their civil laws, federal control over the appellate system in the Canadian judicature should not prevent these provinces from vesting final control over the administration of their civil laws in their own courts. If the Constitution is to be both flexible and federal, the possibility of judicial self-government for the provinces in matters constitutionally assigned to them should be neither mandatory nor impossible.

The federalist grounds for this reform are reinforced by the widespread view that the Supreme Court spends a disproportionately large part of its time and energy on trivial private-law cases. The jurisdictional source of a majority of the Court's cases is the litigant's statutory right to have the Supreme Court review any final judgment of a provincial court of appeal, whereever at least $\$ 10,000$ is at stake in the controversy. ${ }^{74}$ Most of these cases do not involve matters of any great consequence; more often than not they are cases governed by laws subject to provincial legislative authority. Adjudication of these cases by the Supreme Court constitutes an extravagant misuse of the Court's energies. Also, from the litigant's point of view, this jurisdiction makes litigation unnecessarily expensive and prolonged. Since the Supreme Court's establishment in 1875, appellate courts have been established in every province. ${ }^{75}$ Thes courts are now able to provide provincial litigants with the basic right to have the trial court's judgment reviewed by an appellate tribunal. A further appeal to the national Supreme Court should lie only where the decision in question raises some issue of importance to the whole nation.

73 Edward Blake once explained the advantage of vesting final legislative and judiclal control over local matters in parallel institutions in these terms: ".. . it seems to me to be perfectly clear that, theoretically, if you are framing a federal constitution the same legislative jurisdiction which makes the law ought to create the functionaires who are to interpret it: so that if your local judges go wrong, it is your local legislatures that can correct them. If they say: Now, we interpret this law to mean so and so, and if theoretically, the Legislature finds that it is contrary to their meaning and intention in passing the law, they can alter the law, and make it clear, and they intention in passing the law, they can alter the law, and make it clear, and they the Legislature intended the judicial interpretation should be." (1885) H.C. Deb. 158. For a broader and more recent statement of the merits of restricting appeals to the Supreme Court in provincial law matters, see Abel, The Role of the Supreme Court in Private Law Matters (1965), 4 Alta. L. Rev. 39.

74 R.S.C. 1952 , c. 259 , s. 36.

75 Ontario and Quebec had established appellate divisions of their superior courts before 1875. Appeal courts were established in Manitoba in 1906. British Columbia in 1907, New Brunswick in 1913. Saskatchewan in 1915, Alberta in 1919 and Nova Scotia in 1963. Although neither P.E.I. nor Newfoundland have yet established specialized appeal courts, they now have four superior court judges so that three judges are avallable to review superior court trial judgments. P.E.I.'s fourth judge was added in 1960, and Newfoundland's in 1963. 
The need to reform the Supreme Court's jurisdiction so that it is free to devote itself to the adjudicative functions befitting the nation's highest court has been recognized for some time. It is true that reform of this kind does not require constitutional change; the federal parliament could and should amend the Supreme Court Act so that appeals are mainly by leave of the Court and the right to appeal is related to actions involving important constitutional or federal rights. ${ }^{\text {i }}$ But the constitutional reform suggested here would mean that the identification of those legal matters of national importance in which final adjudication by the Supreme Court is appropriate would not depend solely on the federal parliament or the Supreme Court's discretion. Negatively, the provincial legislature should, where it wishes to, determine which of the legal matters subject to its jurisdiction are to be ineligible for Supreme Court review. In exercising this power a province may only confirm action taken by the federal parliament or by the Court itself in regulating the Supreme Court's jurisdiction. Nevertheless, the provinces' right to judicial autonomy in matters of provincial concern should not be dependent on the good sense of the federal parliament or the self-restraint of the Supreme Court.

By way of contrast with this proposed "federalization" of control over the appellate system, the two-chamber division of the Supreme Court, which is more frequently advocated as the solution to Quebec's chief complaint about the Court, looks forward to an undesirable continuation of an extensive Supreme Court jurisdiction in private law cases. ${ }^{77}$ Indeed, if the Civil Law and Common Law Chambers of the Court were provided for in the Constitution, this would tend to make the review of decisions dealing with Quebec's Civil Law one of the Supreme Court's most significant permanent functions. Nor does the two-chamber approach avoid the jurisdictional issues which are a likely consequence of the proposal put forward here. If the jurisdiction of the two (or more) chambers is defined in the Constitution (and it is difficult to see how the two-chamber proposal can constitute a significant improvement on the panelling system now in vogue unless it is given a constitutional basis), ${ }^{\text {i8 }}$ then the Court will become involved in sorting out the issues or cases which are governed by Quebec Civil Law just as much as it would under a system in which the Constitution permits the province to terminate appeals to the Supreme Court in those matters. No worthwhile reform can escape the possibility of creating a constitutional basis for challenging the Supreme Court's appellate jurisdiction on division of power grounds. To insist on insulating the Court's jurisdiction from that possibility as section 101 of the B.N.A. Act now does, is to assume that the advantages of federalism are uniquely associated

70 This, for instance, is the general direction which Professor Laskin suggested reform of the Supreme Court's jurisdiction should take: Laskin. The Supreme Court of Canada -The Coffin Case and Amendments to Appellate Jurisdiction (1956), 34 Can. Bar Rev. 966.

77 Professor McWhinney seems to be the only exponent of the multi-chamber solution who considers the alternative approach of limiting appeals in provincial law matters. But he dismisses the latter as the more troublesome alternative. McWhinney. "A Supreme Court in a Bicultural Society-The Future Role of the Canadian Supreme "A Supreme Court in a Bicultural Society-The Future Role of the Canadian Supreme Reports, 12-13. Part $\mathrm{H}$. But it is difficult to understand why restricting appeals in cases determined by provincial law would be more difficult than creating specialized divisions of the Supreme Court.

78 Between 1950 and 1964, $94 \%$ of the appeals from Quebec involving Civil Law were heard by a panel of the Supreme Court on which Quebec judges constituted a majority. Op. cit. supra, n. 26, at 60, n. 1 . 
with the legislative and executive branches of government. In this age of judicial and political realism such an assumption is no longer tenable.

Provincial withdrawal of Supreme Court jurisdiction over provincial law matters would no doubt reduce the Supreme Court's capacity for introducing greater uniformity into the Canadian legal system. ${ }^{79}$ But this denial of jurisdiction could only be effective where the Supreme Court itself was convinced that the key issues in the case were matters of provincial law. ${ }^{80}$ If legal uniformity in these areas is considered essential, then the proper way of realizing it is not surreptiously through the Supreme Court's appellate jurisdiction but by means of a readjustment in the division of legislative powers. As for the so-called "comparative-law" advantages associated with the Supreme Court's combined role as a final appellate court for Quebec's Civil Law as well as for the Common law provinces, ${ }^{81}$ these will by no means disappear in a Court which spends far less of its time adjudicating private-law cases. Civil Law jurists and Common Law jurists can still "enrich" each other by comparing the ways in which their respective legal cultures illuminate the issues which come before the Court. There may be fewer opportunities for "comparative law" in the Supreme Court, but the appropriate place for the cultivation of this particular legal virtue is in the lawschools of the country, not the Supreme Court.

\section{SUMMARY OF PROPOSED CHANGES}

Although the draughting of precise constitutional clauses by private laymen such as this writer, is an even more academic exercise than setting out the general direction of constitutional reform, still, for the purpose of summarizing the foregoing discussion, the above proposals entail the following changes in the B.N.A. Act:

\section{I-Elimination of Sections 96 to 101.}

II-A new section governing the Supreme Court of Canada which will

(A) declare the Court's primary purpose

(B) establish a procedure involving federal and provincial collaboration in the appointment of Supreme Court judges

(C) guarantee the tenure and salaries of the Supreme Court judges

(D) vest authority in the federal parliament to regulate the Court's original and appellate jurisdiction subject to the overriding power of the provinces to vest final appellate authority over provincial law matters in provincial courts.

79 For a discussion of this implication of the Supreme Court's appellate powers see Willis, Securing Uniformity of Law in a Federal System (1944), 5 U. of T. L.J. 352 .

80 One of the jurisdictional issues resulting from this constitutional change which might be anticipated is the question of jurisdiction in the field of conflicts of law where it relates to the choice of provincial laws. Here, where the question at issue is the reach of a province's law beyond its own borders, final adjudication by a federal reach of a province's law beyond its own borders, final adjudication by a federal case of 1938, see M. Hart, Jr. and Wechsler, The Federal Courts and the Federal System 633-36.

81 Chief Justice Rinfret discussed these advantages in Reminiscences from the Supreme Court of Canada (1956), 3 McGill L.J. 1. But not all Quebec jurists have been so sanguine about these possibilities. $\mathrm{Mr}$. Justice Mignault shortly after his appointment to the Court promised that he would ". . . Insist that each system of law be administered according to its own rules and in conformity with its own precedents" (1925), 3 Can. Bar Rev. 23. 
III-Add to the federal legislature's enumerated powers the latter portion of section 101, i.e. the power to establish "additional Courts for the better administration of the laws of Canada." This might be made expressly subject to the limitation now contained in Section 91 (27) "except the Constitution of Courts of Criminal Jurisdiction."

IV-Extension of section 133 along the lines proposed by the Royal Commission on Bilingualism and Biculturalism. 